\title{
VERDADE, FICÇÃO E OS FIOS DE UM ENLINHADO NA FOTOGRAFIA
}

\author{
Jorge Luan Rodrigues Teixeira ${ }^{1}$
}

\begin{abstract}
[A ficção] Não dá as costas a uma suposta realidade objetiva: muito pelo contrário, mergulha em sua turbulência, desdenhando a atitude ingênua que consiste em pretender saber de antemão como é essa realidade. Não é uma claudicação ante tal ou qual ética da verdade, mas uma busca de uma um pouco menos rudimentar

(José Juan Saer, "O conceito de ficção")
\end{abstract}

No ensaio fotográfico abaixo apresentado, produto de uma pesquisa de campo iniciada em 2013, trato sobre a vida em localidades rurais de dois pequenos municípios do sertão cearense. Se ao falar "vida" na frase anterior não qualifiquei que "vida" é essa da qual falo, se não a caracterizei como a vida de trabalhadoras e trabalhadores rurais ou, mais amplamente, a "vida humana", é porque um dos objetivos deste trabalho é justamente descrever o enlinhado de uma vida necessariamente mais-que-humana.

Este texto, que precede o ensaio, não tem como intenção fundamental explicalo ou tornar compreensível uma narrativa sequencial (o que, aliás, não é o caso aqui) que daria nexo à ordem de exposição das fotografias, mas objetiva descrever as limitações e os desafios que enfrentei e qual resposta dei a eles (e mesmo algumas que poderia ter dado ou intentei dar). O que me motiva a escrevê-lo é a percepção de que, no campo das Ciências Sociais e, especificamente, da Antropologia, é indispensável que todos nós compartilhemos as questões éticas e metodológicas por nós enfrentadas, pois elas e as soluções que encontramos apresentam possibilidades para outros pesquisadores. Expondo essas reflexões e escolhas, portanto, almejo contribuir, ainda que minimante, com a(o)s colegas que enfrentem ou venham a enfrentar limitações parecidas ou mais complexas quanto à divulgação das fotografias por ela(e)s realizadas durante as suas pesquisas de campo.

É importante, entretanto, fazer uma ressalva e confessar uma limitação, que servirá para relativizar algo (ou muito) do que se segue. Não tenho formação em

\footnotetext{
${ }^{1}$ Universidade Estadual Vale do Acaraú, Brasil. E-mail: jorge.luant@gmail.com ORCID id: $\underline{\text { https://orcid.org/0000-0001-7729-3823 }}$
} 
Antropologia Visual e, infelizmente, conheço pouca literatura sobre esse campo da disciplina. Meu interesse pela fotografia ocorreu paralelamente ao interesse pela Antropologia, quando, ainda na graduação em Ciências Sociais, fiz um curso de iniciação à fotografia oferecido semestralmente pela universidade em que estudava.

Se, como produto da pesquisa de campo do mestrado e do doutorado, almejei apresentar na dissertação e na tese um ensaio fotográfico, o fazia porque, como fotógrafo, penso que a imagem oferece uma excelente forma de expressão alternativa ao texto escrito, mas também - e este pode ser um exercício de "sincericídio" - porque isso me divertia. A câmera fotográfica e as imagens por ela produzidas tanto permitiriam ilustrar algumas questões críticas dificilmente visualizadas apenas com o texto escrito quanto possibilitariam, na forma de um ensaio, dizer algo mais ou oferecer um ponto de vista diferente, alternativo. Em suma, o que quero dizer é que, realizando a pesquisa de campo, a fotografia me interessava indiretamente enquanto antropólogo, mas o fazia diretamente enquanto fotógrafo.

O texto que se segue está organizado em quatro breves seções. Na primeira delas, apresento um projeto de documentação fotográfica levado a cargo durante a pesquisa de campo do mestrado. A menção é importante na medida em que permite ver a diferença entre aquela proposta e esta que precisei fazer aqui. Em um segundo momento, discuto as questões éticas e metodológicas implicadas no uso e na divulgação das fotografias feitas em campo, o que abre margem para discutir as escolhas técnicas que precisei fazer (e aquelas que quase fiz) para orientar as capturas e a exposição do material, assim como as referências visuais que as orientaram. Em seguida, apresento algumas reflexões sobre o estatuto da fotografia que fundamentaram as escolhas que fiz. Por fim, na última seção, apresento brevemente o tema deste ensaio ao discutir o significado da palavra que lhe dá nome: enlinhado.

Por seu próprio objetivo, optei por uma escrita mais pessoal no decorrer do texto, daí o uso, na maioria das vezes, da primeira pessoa do singular.

\section{Fotografia da luta}

Em 2013, por ocasião da realização do Mestrado em Antropologia Social, iniciei uma pesquisa de campo em dois pequenos municípios do sertão cearense. Estimulado pela leitura de etnografias realizadas desde a década de 1970 por pesquisadores 
vinculados ao Programa de Pós-Graduação em Antropologia Social, Museu Nacional $(\mathrm{UFRJ})^{2}$, sobre este tema no Nordeste brasileiro, a pesquisa tinha como objetivo refletir, décadas depois, sobre as características da 'relação de morada', mas não mais na Zona da Mata, locus daqueles trabalhos, e sim no sertão cearense. O foco estava menos nas relações verticais, entre patrões e 'moradores' ${ }^{3}$, e mais nas relações horizontais, i.e., entre esses trabalhadores, sua família nuclear e outros parentes, vivessem eles na mesma propriedade ou não. Assim, visando entender as trajetórias de vida e os deslocamentos realizados por esses trabalhadores e suas famílias entre diferentes propriedades rurais, $\mathrm{o}$ trabalho, a mobilidade e o parentesco foram temas chave na dissertação de mestrado (Autor, 2014a). Em diálogo com os trabalhos acima referidos, percebia que a localização de trais trabalhadores rurais no sertão cearense e as mudanças sociais e econômicas pelas quais o Brasil passou na primeira década do século XXI colocavam algumas questões diferentes às reflexões clássicas sobre "reprodução social do campesinato".

Quando tratavam da sua própria trajetória de vida e da rotina de trabalho duro e sofrimento que atravessavam, sobretudo no 'tempo de antigamente', os interlocutores costumavam utilizar o conceito de 'luta'. Com o emprego dessa palavra, expressava-se, em um sentido restrito, a concepção do trabalho "como um permanente dispêndio de forças, de energia e de saúde" (Sigaud, 1978: 60); mas também, em sentido mais amplo, "tudo aquilo que se é obrigado a enfrentar no dia a dia para viver dignamente" (Comerford, 1999: 28). Naquele sentido específico, 'lutar' descreve o choque entre duas forças opostas: a dos trabalhadores, que empregam suas energias corporais e mentais, e daqueles com/contra quem lutam: os patrões, outros moradores, os instrumentos de trabalho, o gado, os predadores dos rebanhos, as cercas, a lavoura, etc. É essa forma de ação e de embate que permite aos trabalhadores obter um 'ganho', 'criar' os filhos, ter comida para colocar na mesa. Entretanto, para além do suor e do desgaste físico, indispensáveis para a produção de valor econômico, o que está em jogo, ao fim e ao cabo,

\footnotetext{
${ }^{2}$ Os trabalhos aos quais me refiro são variados, mas aqui cabe mencionar aqueles de Moacir Palmeira (2014 [1971], 1977), Lygia Sigaud (1978, 1979) e Doris Rinaldi Meyer (1979).

3 'Moradores' são trabalhadores rurais cujo acesso à terra e a uma 'casa de morada' é condicionado por um proprietário rural, doravante seu patrão, para quem trabalha. Há uma diversidade de arranjos possíveis, mas, em geral, o 'morador' cede uma porcentagem da sua produção agrícola ao dono da terra, produção essa que pode ser de um gênero agrícola específico ou de todos aqueles cultivados. O morador também está à disposição do patrão para a realização de serviços variados (pagos, na maioria das vezes) na propriedade. No sertão nordestino, para além de agricultor, o 'morador' pode ser também vaqueiro, cuidando dos rebanhos bovinos, caprinos e/ou ovinos. Na região por mim estudada, o pagamento dos vaqueiros ou se dá 'na sorte' (1/4 ou 1/5 dos bichos nascidos) ou por meio de 'salários', pagamentos em dinheiro vivo que, não obstante o nome, são bastante inferiores ao salário-mínimo legal.
} 
é a produção de valor moral, de alguém enquanto 'trabalhador' - descrever alguém com esse termo, aliás, é um grande e dignificante elogio. 'Lutar', então, qualifica moralmente aquele que trabalha na medida em que isso afirma a sua 'coragem' e empenho para prover a família e obter 'progresso', 'melhora', não obstante as dificuldades inerentes à condição de 'pobre' que trabalha 'na terra dos outros', que 'pastora o alheio'.

Constatando o poder da 'luta' na composição de mundo dos interlocutores e o seu potencial analítico, apresentei na dissertação um ensaio que lançava mão das fotografias como recurso de "tradução" daquele conceito nativo ${ }^{4}$ : elas permitiam dizer algo que eu não saberia (e não sei) expressar fazendo uso de palavras. Por ser incapaz de expressar isso em um texto escrito, optei por não usar legendas - opção que também adoto aqui, como se verá -, o que era também um desafio autoimposto: tornar compreensível o ensaio fotográfico sem a intromissão da palavra escrita acompanhando cada imagem (ver as fotografias na página seguinte).

$\mathrm{Na}$ concepção do ensaio, na realização das capturas, na edição das fotografias (realizadas com uma câmera digital de pequeno formato), na opção pela monocromático e na sua apresentação era forte a influência da Fotografia Documental e dos registros de fotodocumentaristas que tomaram o trabalho e as classes trabalhadores como tema. Tratase de uma rica tradição que tem como expoentes fotógrafa(o)s como Jacob Riis, Lewis Hine (aliás, além de fotógrafo, sociólogo), Walker Evans e Dorothea Lange. A linguagem dessa tradição documental me pareceu a mais apropriada para falar sobre a 'luta', mas, para ser sincero, era também aquela que mais conhecia e com a qual mais me identificava, talvez por ter tido como professores fotógrafa(o)s documentaristas e fotojornalistas que com ela também se identificavam.

A câmera fotográfica acabou se tornando uma personagem da pesquisa de campo, assim como as fotografias que, impressas, eu entregava aos interlocutores, o que produzia excelentes feedbacks e acabava funcionando como um catalizador para conversas variadas, como observado por Achutti (1997: 66). Obter a autorização prévia dos interlocutores para a divulgação das imagens não foi difícil. No mais, de minha parte, não havia dilemas éticos envolvidos quanto à utilização e à divulgação das fotografias que foram de fato divulgadas, pois estava tratando de um tema que afirmava a virtude e a

\footnotetext{
${ }^{4}$ Algumas dessas imagens foram depois publicadas em revista acadêmica (Rodrigues Teixeira, 2014b) e apresentadas na mostra do prêmio Pierre Verger durante a 29a Reunião Brasileira de Antropologia, ocorrida em 2014 em Natal (RN).
} 
condição de 'trabalhadores' dos sujeitos da pesquisa. A divulgação, embora provocasse risos entre eles pelo inusitado de algumas capturas, foi apreciada.
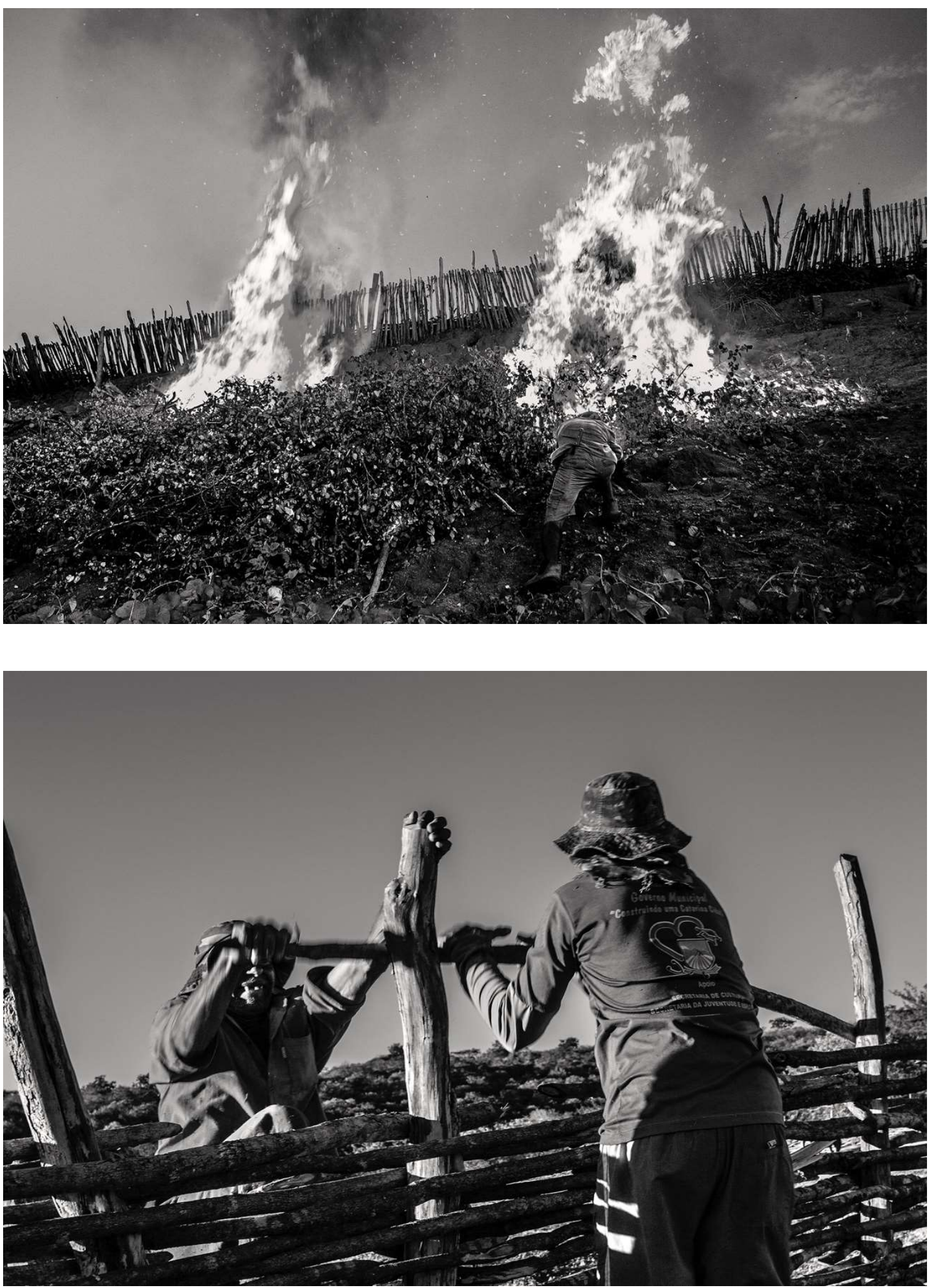


\section{Outra pesquisa, soluções possíveis}

A partir de 2014, embora permanecesse pesquisando na mesma região e mantivesse muito daqueles 'moradores' como interlocutores e amigos, o foco da pesquisa mudou significativamente: passei a me interessar pelas relações entre humanos e animais, inflexão produzida inicialmente pelo interesse sobre o dilema ético colocado pelos ataques de cães a rebanhos animais - tema, aliás, de artigo publicado em parceira com Autora nesta revista (Autor \& Autora, 2016).

Tal como na pesquisa do mestrado, minha intenção era novamente apresentar um ensaio fotográfico que contribuísse efetivamente na construção e na exposição do argumento da tese. Nesse sentido, tanto na dissertação quanto na tese, embora não almejasse e nem tivesse capacidade de realizar um projeto como o seu, a provocação colocada por Achutti em sua proposta de "fotoetnografia" servia como estímulo:

\footnotetext{
Não interessa ao presente trabalho a já consagrada forma de utilização da fotografia como ilustração, como material de adorno de dissertações e de trabalhos de pesquisa. Interessa sistematizar as potencialidades da fotografia enquanto técnica de pesquisa e, principalmente, enquanto possibilidade de construção de uma forma narrativa eficaz (1997: 56).
}

Com esse intuito, fui à campo munido de uma câmera analógica de médio formato e iniciei ali um projeto de documentação. A intenção do projeto de pesquisa nesses momentos iniciais era ainda bastante aberta: almejava refletir sobre as relações entre humanos e animais tendo como foco a caça e o pastoreio. Os cães eram a dobradiça, o elo que unia as duas atividades.

A pesquisa sofreu, contudo, uma inflexão motivada por contingências profissionais e pela impossibilidade de permanecer em campo por um longo e ininterrupto período de tempo: do interesse mais amplo pelas relações entre humanos e animais, centrei a atenção nas atividades de caça desenvolvidas por 'moradores' e pequenos proprietários rurais. Na tese, meu objetivo foi pensar a vida dos meus amigos sertanejos tomando a prática venatória como centro temático ao redor do qual a descrição etnográfica "gravitaria" (Autor, 2019). A meu ver, tratava-se de uma proposta alternativa de pensar o campesinato não por uma via agrocentrante, mas a partir da caça e da relação dos sertanejos com as matas. 
Embora, olhando de hoje, tenha sido essa a melhor escolha que fiz em razão das limitações que o trabalho me colocava e também pelo resultado que obtive, a mudança de foco acarretou um sério problema no andamento daquele projeto de documentação fotográfica. Provavelmente, o teria ferido de morte.

Digo isso porque uma condição necessária para a realização do trabalho sobre caça foi, justamente, sob nenhuma hipótese identificar os interlocutores, dada a ilegalidade e a controvérsia política e moral das práticas a serem descritas. Se os pseudônimos (criados em colaboração com os próprios interlocutores) e uma toponímia fictícia poderiam resolver parte significativa dos potenciais problemas no que diz respeito ao texto escrito, não me pareceu possível fazer algo similar com os muitos rolos de filme já fotografados e revelados. Pela forma como concebia o ensaio e fiz as capturas, i.e., ainda em diálogo com aquela mesma tradição fotográfica acima mencionada, os interlocutores seriam identificados e, dessa forma, eu fatalmente 'quebraria nosso trato'. A situação era, portanto, bastante diferente daquela de Caetano Sordi - autor de um ensaio fotográfico sobre a "caza menor" na Andaluzia, Espanha, publicado nesta revista (Sordi, 2016) -, na medida em que ele registrava uma modalidade de prática venatória esportiva legal.

Frente a isso, que fazer? À altura, divisei três possibilidades, sendo a terceira delas a que levo a cargo aqui. Apresento essas duas outras alternativas aqui por pensar que elas podem fornecer pistas para colegas que enfrentem situações de algum modo similares àquela referida no parágrafo anterior.

A primeira delas, ainda em diálogo com aquela tradição da fotografia documental, foi inspirada por uma única fotografia de Dorothea Lange no seu projeto de documentação a serviço da "Farm Security Administration" no âmbito da Grande Depressão precipitada pela crise de 1929. A fotografia, datada de 1937 e intitulada "Hoe Culture, Alabama”, apresenta um trabalhador agrícola com uma roupa desgastada que posa no campo para a fotógrafa. As mãos, ao centro da fotografia, repousam sobre o cabo de um instrumento agrícola que, pelo título da captura, supõe-se ser uma enxada. O que dá expressividade a essa imagem é justamente o que ela não mostra: o rosto do agricultor. O plano da fotografia de Lange vai dos ombros do trabalhador aos seus joelhos e, portanto, não permite identificá-lo. Um agricultor singular, mas que, não identificado por meio do seu rosto, são todos os agricultores. E isso, em alguma medida, não nos faz lembrar Walter Benjamin ao afirmar que, "nas antigas fotos", nas primeiras décadas da 
história da fotografia, "A aura [da obra de arte] acena pela última vez na expressão fugaz de um rosto [...]" (1987: 174)? Refletindo em seguida sobre a novidade e genialidade da obra de Eugène Atget - que em muitas de suas fotografias prescinde de figuras humanas ao apresentar o espaço urbano como vazio -, Benjamin observa que, com ele, “[...] as fotos se transformam em autos no processo da história. Nisso está sua significação política latente. [...] A contemplação livre não lhes é adequada. Elas inquietam o observador, que pressente que deve seguir um caminho para se aproximar delas" (ibid: 174-5).

A fotografia de Dorothea Lange apresentava, pois, uma solução. Expandindo essa forma de registro e tomando esse enquadramento como o mote de todo o ensaio, falaria não apenas dos sujeitos fotografados ou dos sertanejos e dos trabalhadores rurais, mas também, indiretamente, das condições e das exigências éticas de realização desse ensaio fotográfico. Sem mostrar, mostrava, e, ao fazê-lo repetidamente em diferentes imagens, também mostrava sutilmente as razões de ter operado como operei assim como deixava ver os limites e as responsabilidades éticas indispensáveis à prática etnográfica.

Algumas capturas foram feitas com essa ideia em mente e, embora não tenha sido essa escolha que apresento no ensaio abaixo, reproduzo algumas delas aqui pela primeira vez (ver as fotografias na próxima página).

A segunda possibilidade foi também inspirada, em certo sentido, por aquela fotografia de Dorothea Lange, mas ela seria produto de uma estratégia mais radical. Ao invés de passar a realizar capturas como as acima mencionadas, o ensaio traria as fotografias que já vinha fazendo (e que continuei fazendo), nas quais era possível identificar os interlocutores. Faria, contudo, uma intervenção diretamente no negativo: ao danificá-lo parcialmente, não permitiria, no positivo, divisar o rosto dos sujeitos fotografados. Cometer um "crime": danificar de maneira irreversível o documento, motivado por compromissos éticos e políticos, romper sua aura intocável. A proposta, pois, seria destruir parcialmente o "Documental" da expressão "Fotografia Documental", o que também serviria para chamar atenção para a ambiguidade e as limitações desse qualificativo, na medida em que assim ressaltaria a dimensão necessariamente manipulativa de todo empreendimento fotográfico (Fontcuberta, 2010). Nesse caso, saltaria à vista ainda mais intensamente a questão da representação, da responsabilidade do fotógrafo com os sujeitos fotografados. Entretanto, fazendo-o, seria esse o tema do ensaio, não aquilo que as fotografias, sem a intervenção, teriam apresentado. 

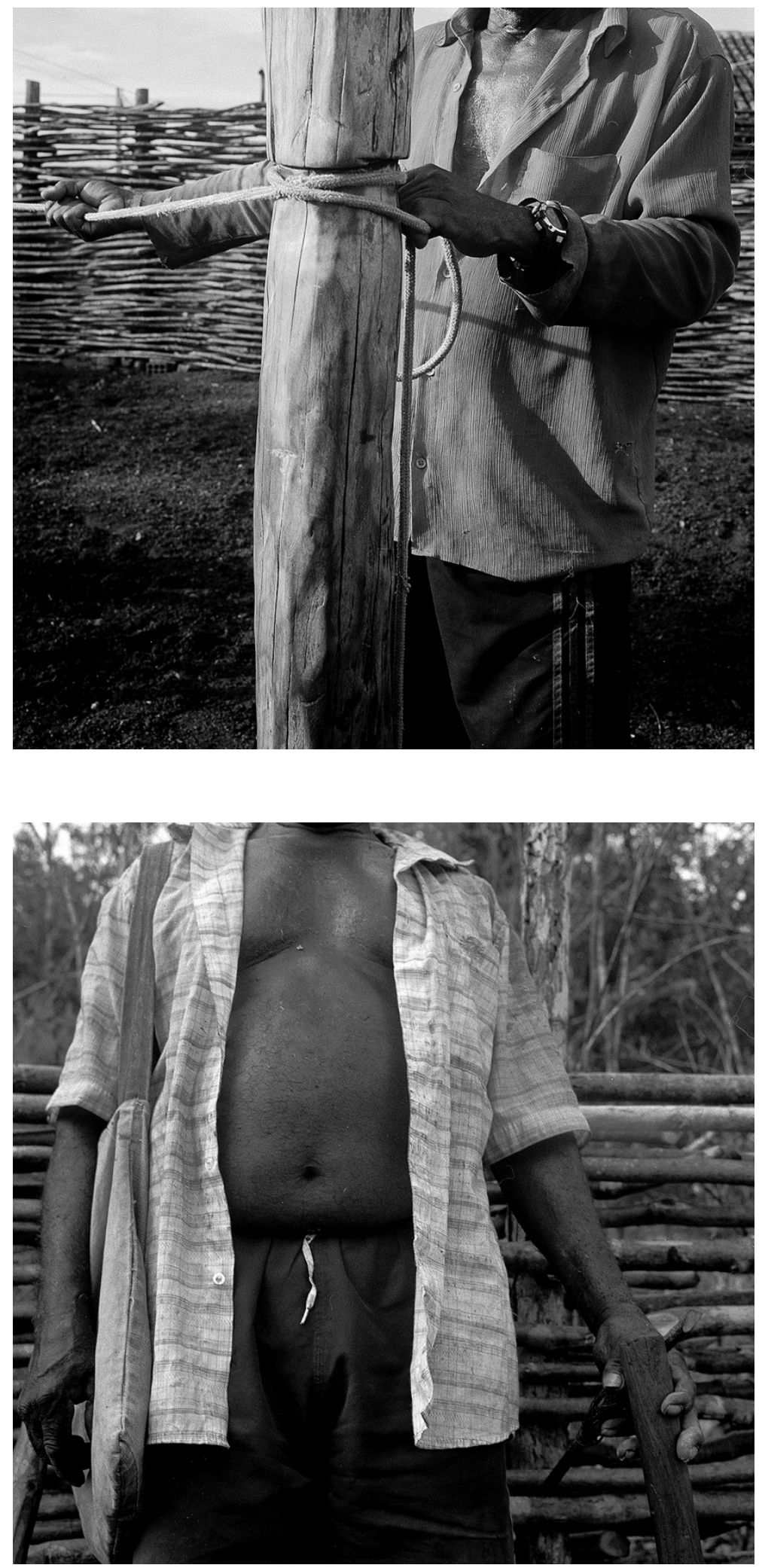
A terceira possibilidade, aquela de fato apresentada abaixo, seria levar a sério outro projeto fotográfico que até então tomava como mero passatempo, e isso explica a utilização das câmeras de aparelhos celulares e o caráter não sequencial do ensaio aqui apresentado. Como se verá, não é possível identificar as pessoas retratadas em razão do ângulo das capturas. No mais, a não sequencialidade, a "forma" do ensaio no que tange ao ordenamento das fotografias, era também parte indispensável do seu "conteúdo", da sua mensagem.

Duas referências visuais fundamentaram e inspiraram de maneiras diferentes a realização do ensaio: os trabalhos dos fotógrafos cearenses Tiago Santana e Silas de Paula (esse último, na verdade, capixaba de Castelo radicado há anos no Ceará).

A obra de Tiago Santana (p.ex: Santana, 2000; Santana \& Dantas 2006) é marcada pela forte influência da linguagem documental, por um complexo jogo de luz e sombra no preto e branco e, em inúmeras capturas, pelo "desrespeito" à distância hiperfocal ao deixar o primeiro plano (um primeiro plano que tão pouco e tanto se deixa ver) ligeiramente fora de foco. A um só tempo complexas e singelas, muitas fotografias de Santana atraem pelo que há de profundo nos detalhes que ele mostra (ou sugere). Sem qualquer pretensão de fazer isto com a qualidade de Santana, essa capacidade de sugestão por meio do detalhe orienta parte significativa das fotografias deste ensaio, assim como o fez quando da sua concepção. É também essa opção pela sugestão que explica a não utilização de legendas. Nos dois casos, o que está em jogo é a famosa provocação e o alerta de Roland Barthes:

\begin{abstract}
Se excetuarmos o setor da Publicidade, onde o sentido só deve ser claro e distinto em virtude de sua natureza mercantil, a semiologia da Fotografia está, portanto, limitada aos desempenhos admiráveis de alguns retratistas. Para o resto, para o tudo-o-que-ver das 'boas' fotos, tudo o que podemos dizer de melhor é que o objeto fala, induz, vagamente a pensar. E ainda: mesmo isso corre o risco de ser sentido como perigoso. [...] No fundo, a Fotografia é subversiva não quando aterroriza, perturba ou mesmo estigmatiza, mas quando é pensativa (1984: 62).
\end{abstract}

Quanto à obra de Silas de Paula, destaco especificamente o ensaio por ele realizado no Mercado São Sebastião, em Fortaleza (CE), ganhador do Prêmio Leica/Consigo $2008^{5}$. Optando pelas cores ao invés do preto e branco, Silas de Paula

\footnotetext{
5 As imagens em questão podem ser conferidas na página do "Flickr" do fotógrafo: https://www.flickr.com/photos/silasdepaula/albums/72157611593890220
} 
acaba demonstrando a riqueza visual do mercado e torna o cromatismo o protagonista de muitas das imagens.

Entretanto, são dois outros aspectos dessas fotografias que quero destacar. O que chama atenção nesse ensaio, e que inspirou este, foi a escolha do ângulo das capturas, que não permitem identificar plenamente os sujeitos fotografados. No que tange ao ângulo das capturas, há outra razão que me faz destacar a influência do ensaio de Silas de Paula: ao fotografar "de cima", praticamente em $90^{\circ}$ em relação ao sujeito fotografado e, portanto, parodiando o "olho de Deus", o fotógrafo, em alguma medida, evidencia e põe em questão a capacidade representacional do artista e do texto imagético - ou, para falar em termos que talvez nos sejam mais familiares, sua "autoridade" (Clifford, 2008). Era também uma paródia ao narrador onisciente, onipotente e onipresente do romance clássico (ou das formas clássicas de representação, ou, se se quiser, da mais ingênua noção de "representação"): o narrador tudo sabe sobre todos, acompanha todos os seus passos e conhece seus pensamentos, fabulações e intenções mais íntimas.

Gostaria de me demorar um pouco mais neste ponto e no que o fundamenta para o caso da fotografia, embora não haja, necessariamente, novidades naquilo que ressalto na seção seguinte a partir de diálogo com um livro do fotógrafo Joan Fontcuberta.

\section{Direto:Manipulado :: Documento:Arte :: Verdade:Ficção ?}

Já no primeiro texto de "O beijo de Judas", o fotógrafo catalão Joan Fontcuberta afirma ser a "verdade" e o seu avesso o tema da sua obra artística (e do livro), daí afirmar:

Toda fotografia é uma ficção que se apresenta como verdadeira. Contra o que nos inculcaram, contra o que costumamos pensar, a fotografia mente sempre, mente por instinto, mente porque sua natureza não lhe permite fazer outra coisa. Contudo, o importante não é essa mentira inevitável, mas como o fotógrafo a utiliza, a que propósitos serve. O importante, em suma, é o controle exercido pelo fotógrafo para impor um sentido ético à sua mentira (2010: 13).

O debate sobre a objetividade do aparelho fotográfico data dos tempos do daguerreótipo. A câmera, em si mesma, teria a capacidade de copiar fiel e objetivamente a natureza, de modo que "Não é preciso um operador, pois é o 'lápis da natureza' que faz todo o trabalho para nós" (ibid: 19). No cerne dessa discussão, que data do século XIX, está a visão ainda corrente entre muitas pessoas que estabelece a mera contingência do operador do aparelho fotográfico. Fontcuberta chega a relacionar essa concepção à 
Filosofia positivista em sua busca pelas leis que regem a história, a sociedade e a psicologia - "O modelo da fotografia foi guiado por uma obsessão de perfeição e exatidão que só se compreende no contexto histórico do positivismo" (ibid: 72). Outra visão, minoritária, afirma a subjetividade e a intencionalidade do fotógrafo e, portanto, a dimensão autoral de todo empreendimento fotográfico.

A consciência dessa dimensão necessariamente autoral poderia conviver (e conviveu/convive) com aquele enfoque majoritário, como, por exemplo, em certas correntes da Fotografia Documental. Pós-1968, ganha força em certos círculos a convicção de que o "documento" a ser produzido pelo fotógrafo deveria, o máximo possível, colocar de lado as idiossincrasias do fotógrafo de modo a ser o mais objetivo e "real" possível: se não havia, e não poderia haver, neutralidade de fato, ela era uma condição desejável, um ideal ${ }^{6}$. Também era um ideal manipular, alterar e retocar o mínimo possível o cenário e os sujeitos da captura, de um lado, e o negativo e a ampliação, de outro. Esse esforço se deixava ver seja pela defesa da "frontalidade" ao fotografar os sujeitos, seja pelo recurso ao monocromático ou às lentes de $50 \mathrm{~mm}$ (ou um pouco menos) em câmeras de pequeno formato, seja pela exigência de exibir na fotografia as bordas do negativo de modo a comprovar que não houve corte.

Essas duas visões se deixam ver na oposição entre aquilo que Fontcuberta entende como dois programas operativos diferentes na história da fotografia: a "fotografia direta" e a "fotografia manipulada":

\begin{abstract}
A 'fotografia direta' implicava a aceitação de regras de jogo dentro dos limites do que era considerada a técnica fotográfica ortodoxa, o conjunto de procedimentos conceituados como genuinamente fotográficos. [...] Implicava, portanto, por um lado, a espontaneidade e a imprevisibilidade da ação ${ }^{7}$ e, por outro, o respeito à visão óptico-mecânica do meio. Por outro lado, a 'fotografia manipulada' supunha a inclusão de efeitos plásticos praticados por outras disciplinas (o desenho, a pintura, as técnicas de gravação etc.) e legitimava qualquer recurso que o fotógrafo quisesse introduzir. Onde uma privilegiava o fortuito e a intuição, a outra o fazia com o planejamento e o controle do resultado (2010: 82 ).
\end{abstract}

Embora os dois programas operativos possam influenciar (e tenham influenciado) a obra de diferentes fotógrafos, a dicotomia era/é, na prática, para lá de

\footnotetext{
6 Para certas correntes, contudo, esse esforço de neutralidade e "realidade" na captura poderia estar justamente a serviço do ideal político da(o) fotógrafa(o) ou cineasta.

${ }^{7}$ E é nesse sentido que podemos compreender a aura mágica do conceito de "instante decisivo" na obra do famoso fotógrafo francês Henri Cartier-Bresson.
} 
problemática, embora conveniente para os néscios. A pergunta a ser feita e que evidencia o problema da dicotomia é a seguinte: "[...] a fotografia manipulada se converte em 'manipulada' depois de quantas 'manipulações'?” (ibid: 83). Ao escolher determinado ângulo para a captura, está-se manipulando a imagem produzida, mas também ao escolher qual lente usar, qual profundidade de campo a ser utilizada, qual filme empregar e de que forma revelá-lo, etc. Toda fotografia é ficção e invenção, toda fotografia é manipulada mesmo quando o operador do aparelho fotográfico se converte em seu "funcionário" ao seguir o programa automático nele inscrito (Flusser, 2011), daí a tautologia na expressão "Fotografia Manipulada" (Fontcuberta, 2010: 84).

Aliás, esse já era um ponto destacado por Walter Benjamin no famoso "A obra de arte na era de sua reprodutibilidade técnica" ao destacar o que chama de "perfectibilidade" do cinema (que permitia ao cineasta, com metros e mais metros de negativo, montar o filme de diferentes maneiras) em contraposição ao "valor eterno" das obras de arte na Grécia Antiga: “[...] a mais alta das artes era a menos perfectível, a escultura, cujas criações se fazem literalmente a partir de um só bloco" (1987: 176). O que Benjamin diria do aumento significativo da capacidade de armazenamento de imagens por meio de cartões de memória, HDs externos e upload em nuvens?

Se “A verdade é um assunto acidentado", isso não é necessariamente o caso com a "verossimilhança" (Fontcuberta, 2010: 104), de modo que "A manipulação [...] está isenta per se de valor moral. O que de fato está sujeito ao julgamento moral são os critérios ou as intenções que se aplicam à manipulação. E o que está sujeito ao julgamento crítico é a sua eficácia" (ibid, ibidem).

Ao chamar atenção para a centralidade da verossimilhança no julgamento das obras fotográficas e para a manipulação inerente a elas, Fontcuberta me faz lembrar as considerações do escritor argentino José Juan Saer ao discorrer sobre o conceito de ficção e a sua relação com a noção de verdade na literatura. Ao afirmar que a segunda não contradita necessariamente a primeira e problematizar a correlação termo a termo dessa oposição com aquela entre subjetividade e objetividade, Saer afirma que a marca da ficção é misturar o empírico e o imaginário, de modo que aquilo que exista de "falso" nela aumente a sua credibilidade - qualidade que ele vê, por exemplo, na obra de Jorge Luis Borges ${ }^{8}$. A "dependência hierárquica entre verdade e ficção", que tenderia a qualificar

\footnotetext{
${ }^{8}$ Há um curioso e famoso exemplo do contrário. Millôr Fernandes, escrevendo em 1988 para o Jornal do Brasil, em sua crítica bem-humorada ao livro "Brejal dos Guajas", de José Sarney, evidencia que mesmo as informações mais banais e prosaicas contidas na (com excessiva boa vontade) "obra literária" são eivadas
} 
positivamente a primeira, não passa de "mera fantasia moral" (Saer, 2009: 2). Por suas próprias características, "A ficção se mantém à distância tanto dos profetas do verdadeiro quanto dos eufóricos do falso" (ibid, ibidem). Daí, segundo Fontcuberta, como expresso no início desta seção, o imperativo de o fotógrafo controlar bem a sua mentira e dar um sentido ético a ela.

Em suma, se poderia dizer, com Vilém Flusser, que "O que vemos ao contemplar as imagens técnicas não é 'o mundo', mas determinados conceitos relativos ao mundo, a despeito da automaticidade da impressão do mundo sobre a superfície da imagem" (2011: 31). Da forma como compreendo a utilização da fotografia na Antropologia, esses "conceitos relativos ao mundo" são tanto aqueles utilizados pelo etnógrafo (ou, se se quiser, os da própria disciplina) quanto aqueles dos interlocutores em sua relação com o seu mundo, devendo as imagens, organizadas na forma de ensaio fotográfico, permitir visualizá-los ou compreendê-los sob um ponto de vista alternativo, complementar. Esse é um trabalho de "ficção", se com essa palavra designarmos aquilo é produzido, modelado, em um esforço de tecer "uma [ética da verdade] um pouco menos rudimentar" (Saer, 2009: 2). Foi essa a minha intenção no ensaio sobre o conceito de luta (Autor, 2014a, 2014b) e é também aqui no que tange ao que chamei, alargando o significando de uma palavra sertaneja, de enlinhado ecológico (Autor, 2019).

Nos termos de Achutti, ao pensar sobre a fotografia como linguagem e na sua aproximação com a Antropologia, "uma vez liberta dos grilhões que a prendiam à realidade, ela melhor poderá desempenhar o papel de estampar interpretações de nexos simbólicos e sociais" (1997: 56). Nesse esforço, superado também o seu mero papel de "ilustração" ao texto escrito, é de fundamental importância compreender, como apontado acima, que a forma é parte indispensável do conteúdo da mensagem ${ }^{9}$, daí a possibilidade de experimentação no que tange à concepção e à apresentação das fotografias. Veja-se nesta revista, por exemplo, o incrível ensaio de Sophia Ferreira Pinheiro (2017).

de falsidade e não resistem a uma simples regra de três. Embora seja, confessamente, uma "ficção" com pretensão de crítica social, "Brejal dos Guajas", como Millôr Fernandes deixa ver, passa longe de ser uma ficção crivel.

9 Ter consciência disso também permite compreender um aspecto importante já observado por Etienne Samain (1995) ao estudar o uso da fotografia na obra de Bronislaw Malinowski: as influências teóricas (e artísticas, obviamente) do etnógrafo influenciam o modo como ele fotografa. Se não tanto naquilo que fotografa - ou mesmo se o faz -, no "como" fotografa, na forma assumida pelas imagens, no lugar por elas ocupado e no que se almeja produzir a partir delas. 
Cito outros dois exemplos de trabalhos de artistas que podem nos fazer - a(o)s antropóloga(o)s - considerar outras possibilidades de utilização da fotografia em nossas próprias pesquisas.

O primeiro deles é aquele da fotógrafa Claudia Andujar (2005), suíça naturalizada brasileira. Em seu ensaio sobre os sonhos dos Yanomami, a fotógrafa faz uso de sobreposições de imagens para expressar a viagem onírica dos xamãs pelo cosmos, assim como a centralidade do corpo e a capacidade transformacional de humanos e animais entre os povos das Terras Baixas Sul-Americanas.

O outro ensaio, intitulado "Paisagem Submersa" (Castilho, David \& Motta, 2008), é de autoria dos fotógrafos mineiros João Castilho, Pedro David e Pedro Motta. Prescindindo quase inteiramente de textos escritos em sua apresentação na forma de livro, o projeto coletivo, realizado entre 2002 e 2007, aborda de maneira impactante a experiência de comunidades ribeirinhas que foram obrigadas a se deslocar para outras regiões como resultado da formação do lago da Usina Hidrelétrica de Irapé, situada no Vale do Jequitinhonha, uma das regiões mais pobres do Brasil.

Retornando ao ensaio de Silas de Paula acima mencionado, a dimensão de "paródia" nele presente toca no dilema ético aqui enfrentado: como falar sobre o Outro sem, com isso, acarretar-lhe problemas variados e romper o acordo prévio estabelecido com o etnógrafo? Se os pseudônimos muitas vezes evidenciam uma complexa, e nem sempre bem-sucedida, economia textual que intenta não identificar os interlocutores ou ações e acontecimentos legal e/ou moralmente problemáticos, como proceder em relação ao uso da fotografia (ou do vídeo)?

É importante ressaltar que o uso de pseudônimos na tese de doutorado não buscou impedir que os interlocutores identificassem uns aos outros (o que fariam facilmente se assim entendessem), mas impedir que eles fossem identificados pelos leitores com quem 'não têm conhecimento', i.e., familiaridade e intimidade. Fundamentalmente, impedir que pudessem ser legalmente responsabilizados por alguns dos seus atos.

Tal foi a motivação para a concepção e a apresentação deste ensaio. Ora, com facilidade ainda maior, os sertanejos identificariam a si mesmos, aos vizinhos e aos 
'conhecidos' ao olhar estas imagens, assim como também reconheceriam os lugares em que algumas capturas foram realizadas; mas também aqui a intenção não é evitar que eles identifiquem uns aos outros e sim impossibilitar que os leitores o façam. É, pois, por essa razão que as fotografias tomaram aqueles trabalhos de Tiago Santana e Silas de Paula como inspiração e solução.

\section{Os fios do 'enlinhado'}

No Ceará como um todo (e talvez em parte significativa do Nordeste brasileiro), quando se quer descrever algo confuso ou complicado pode-se dizer que esse é um 'enlinhado'. Uma discussão em um bar que termina em troca de ofensas verbais e físicas; os trajetos e as mudanças que alguém fez entre diferentes propriedades rurais e cidades durante sua vida; a caatinga com seus muitos arbustos, árvores e vegetação rasteira emaranhados; ou a história política do Leste europeu poderiam todos, por exemplo, ser descritos pelos sertanejos como um 'enlinhado' - aliás, nesse último caso, como um 'enlinhado' e dos 'grandes'. Em suma, quando os interlocutores classificam determinada situação como um 'enlinhado', podendo agregar o adjetivo 'grande' ao substantivo, eles estão descrevendo uma multiplicidade de ações, entes e acontecimentos que estão intimamente unidos, relacionados, 'enlinhados'.

Na tese de doutorado, buscando pensar sobre a vida dos sertanejos tomando como fio condutor a prática venatória e a relação deles com as matas, dei-me conta de que essa vida é, necessariamente, mais-que-humana, i.e., que parte indispensável da composição de mundo tecida pelos sertanejos passa pelo seu relacionamento com forças, seres, coisas e ambientes diversos por eles e com eles 'enlinhados'. O trabalho, portanto, dialoga com o esforço recente da Antropologia de questionar a sua própria tradição antropocêntrica (p.ex: Süssekind, 2018) ao investir etnograficamente na criatividade do processo de vida dos nossos interlocutores. Com esse propósito, é importante lembrar a provocação de Anna Tsing: "E se imaginássemos uma natureza que se transformou historicamente com variadas teias de dependência entre espécies?” (2015: 184); assim como a (re)leitura feita por Stelio Marras da definição de Tim Ingold da Antropologia como "Filosofia com gente dentro": "[...] é preciso aí incluir também os animais, as plantas, os objetos, os espíritos, as técnicas, tudo que entra em relação com o humano e 
faz que o humano emerja como humano, mas um humano em variação, um devir humano antes que um ser humano" (2014: 236).

É sobre isso que o ensaio-enlinhado abaixo apresentado deseja falar. 


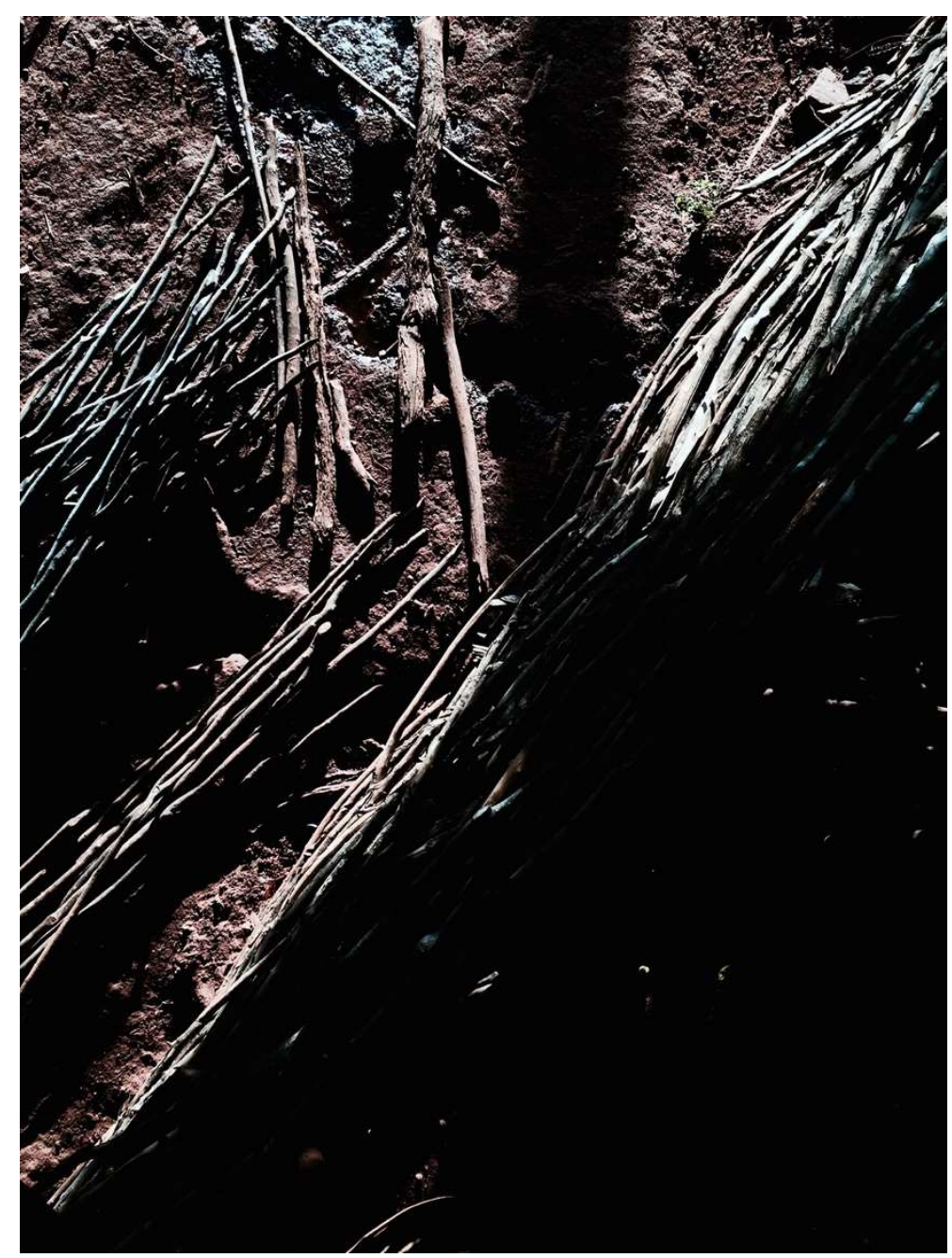



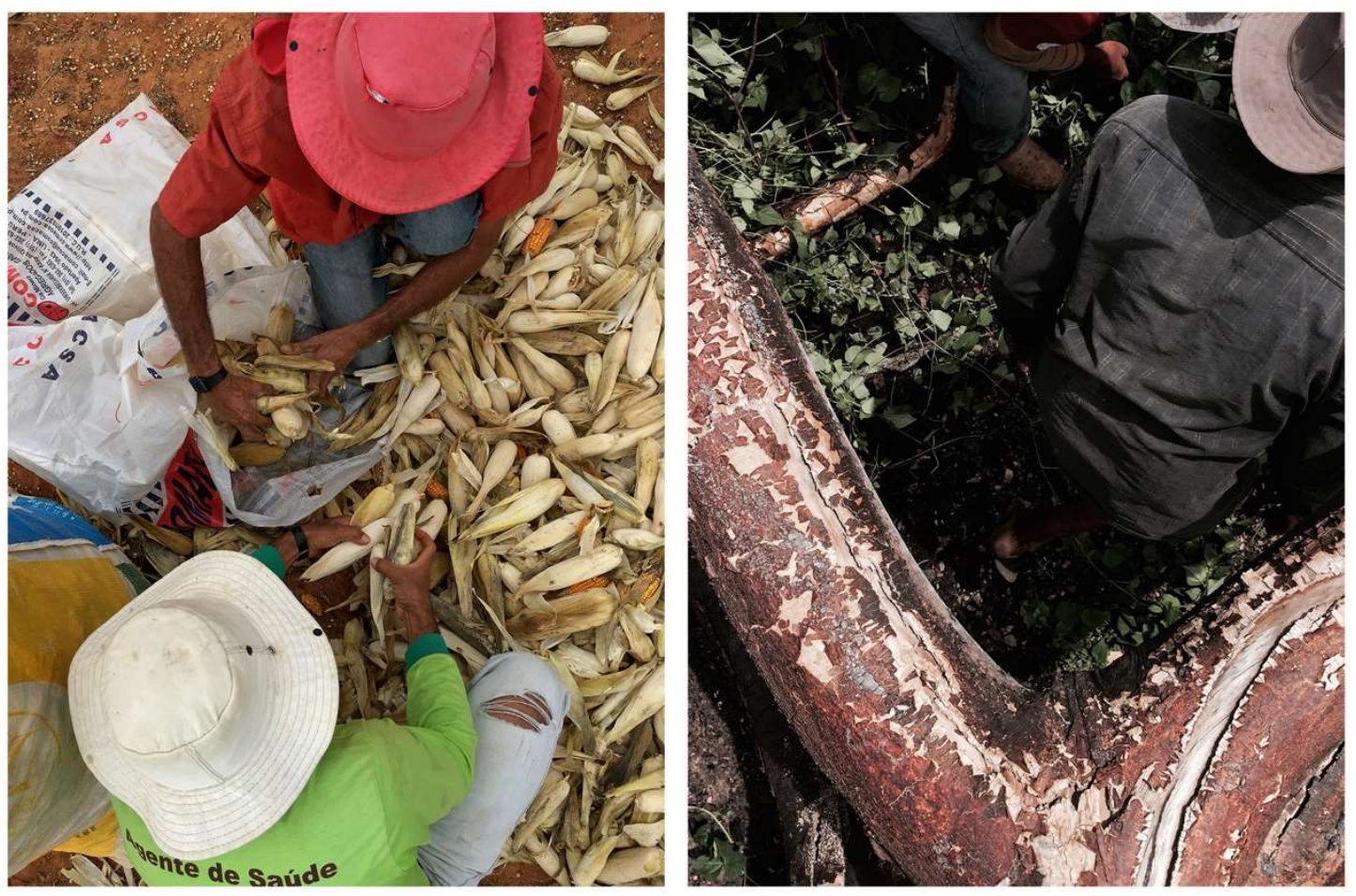

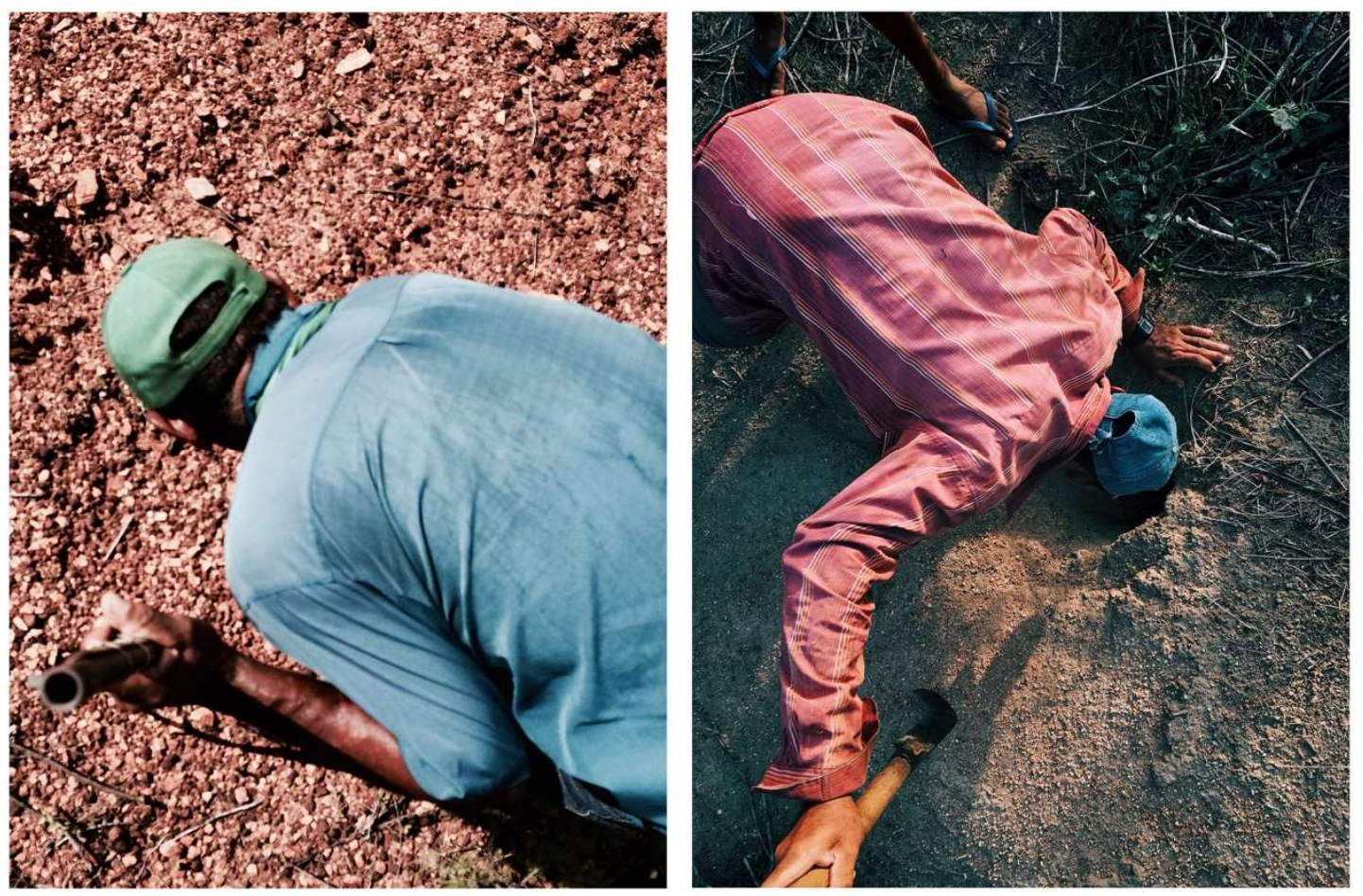


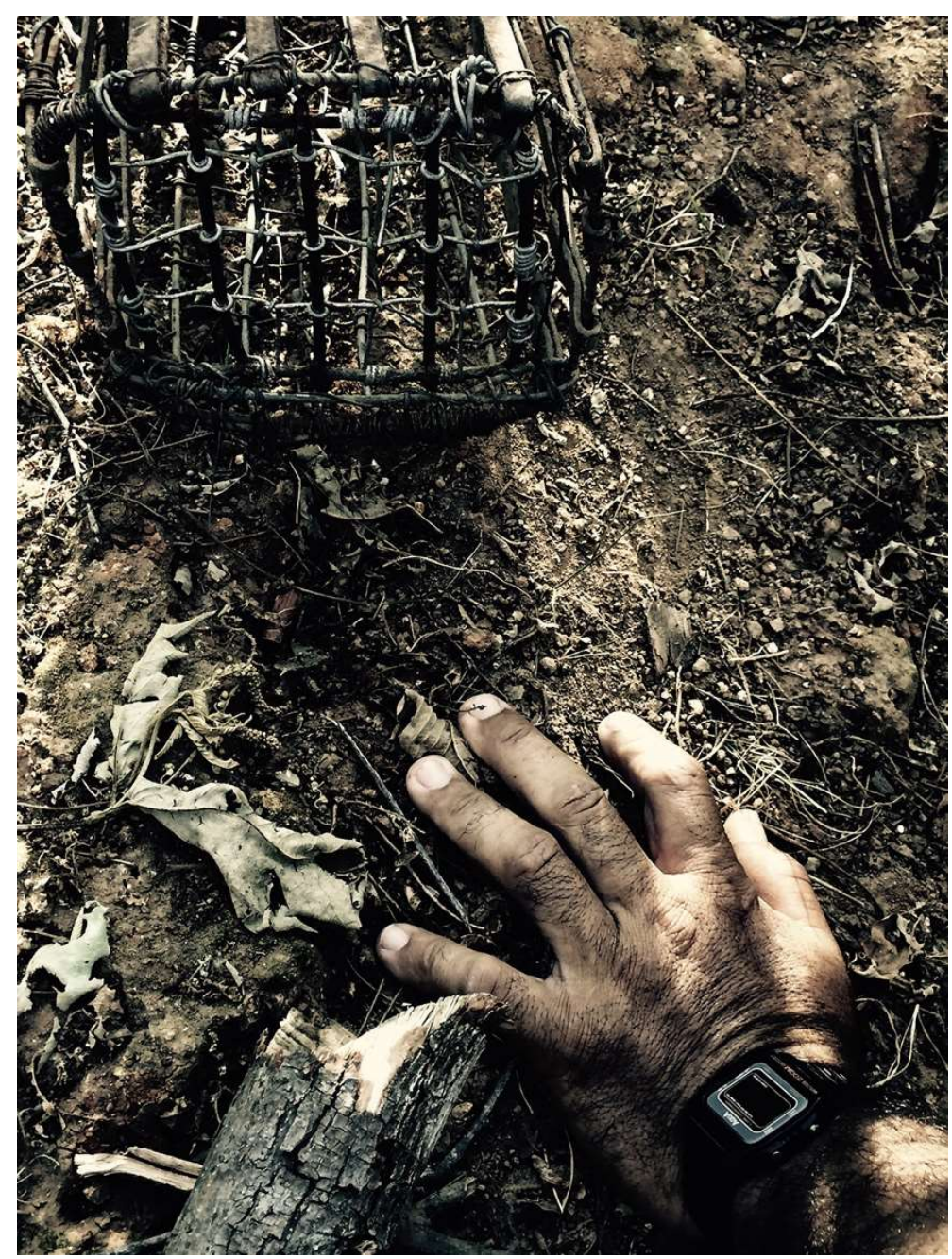




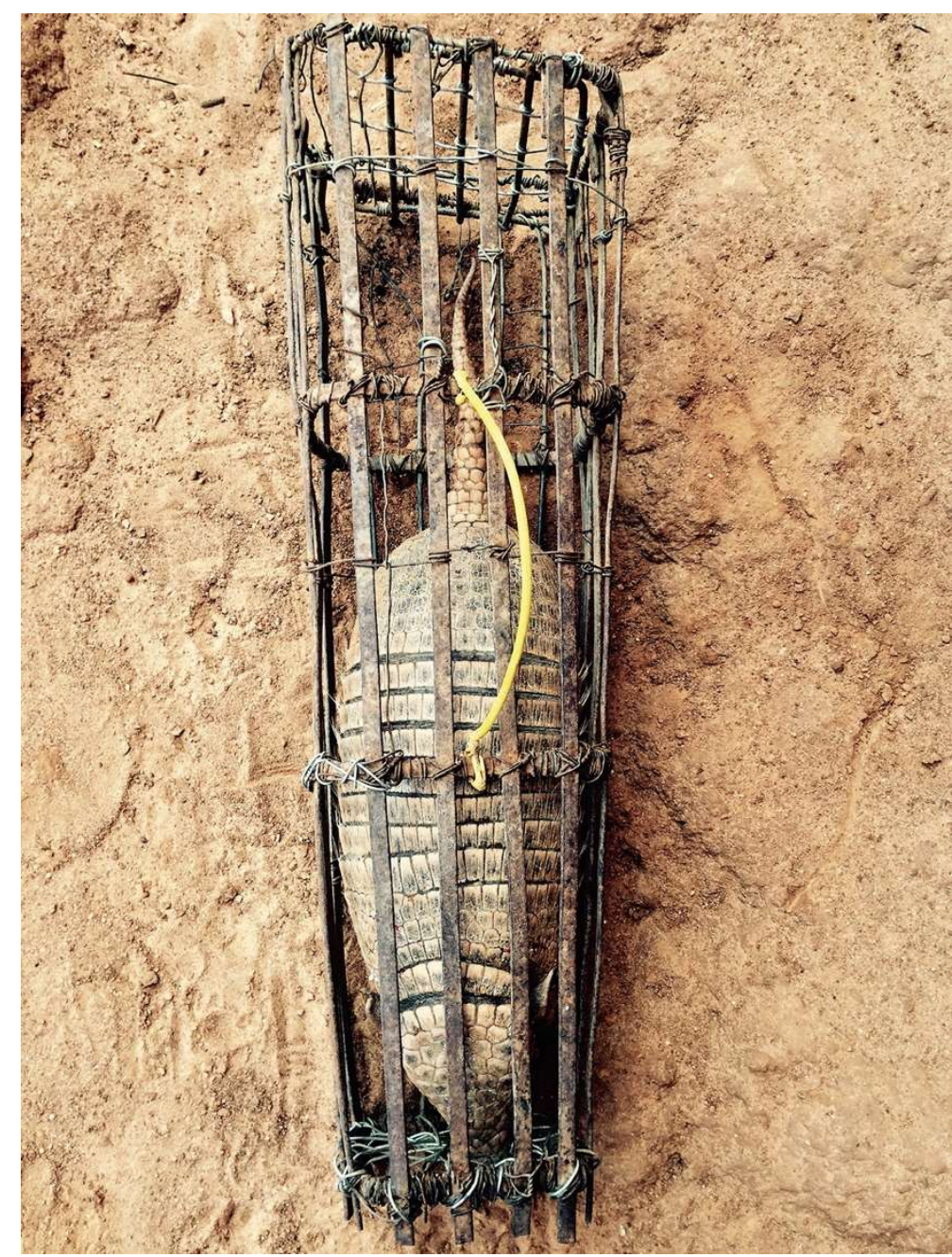




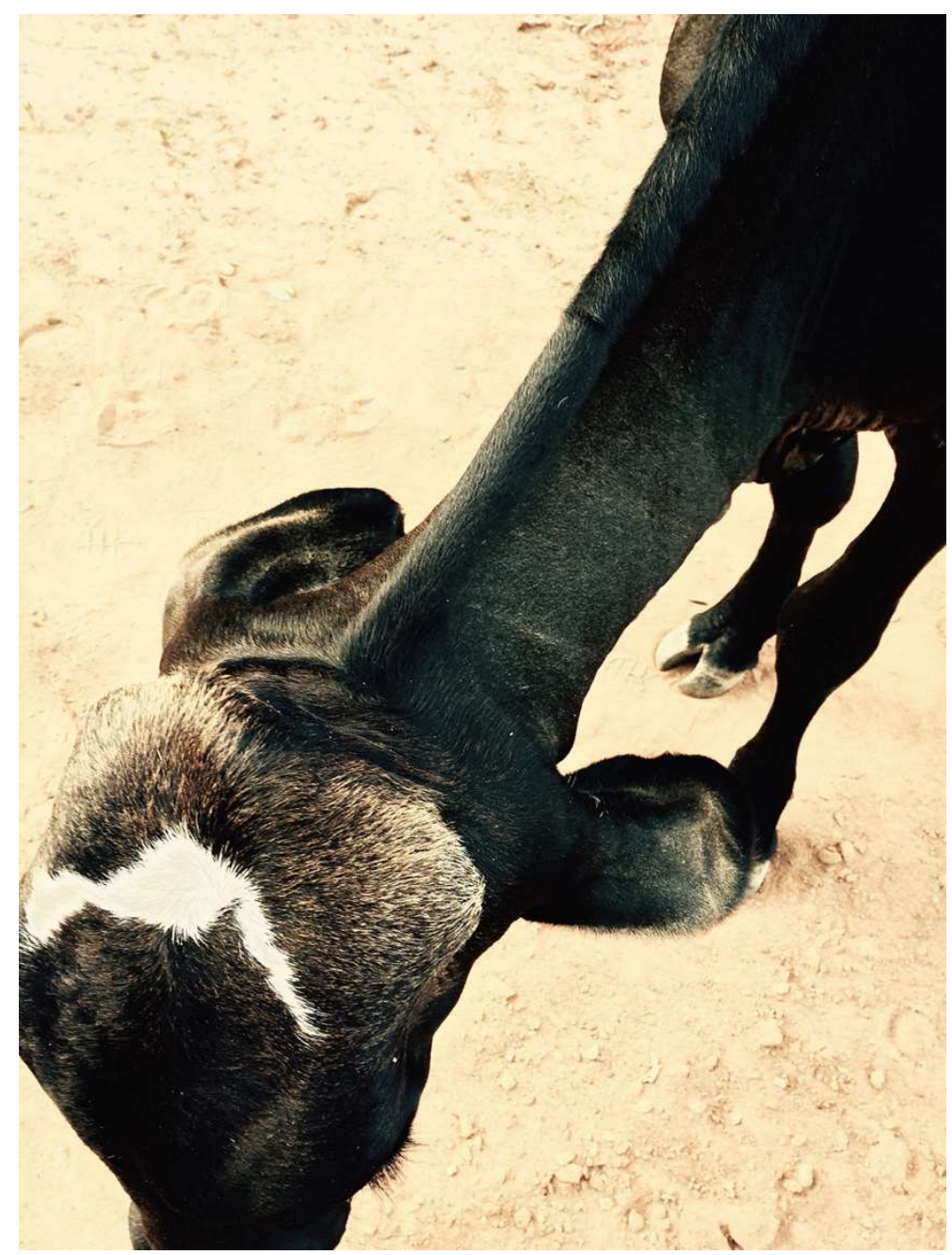



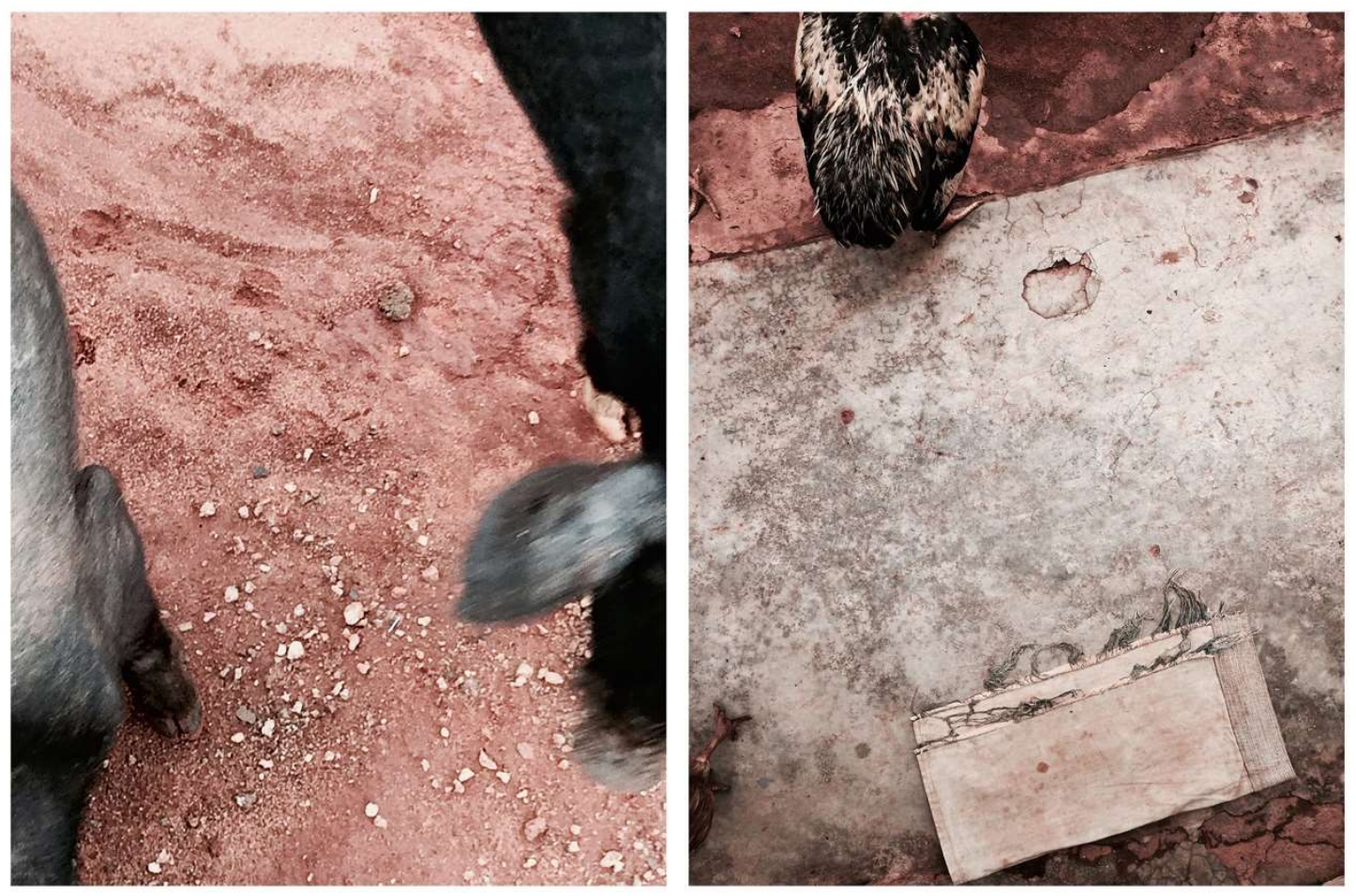


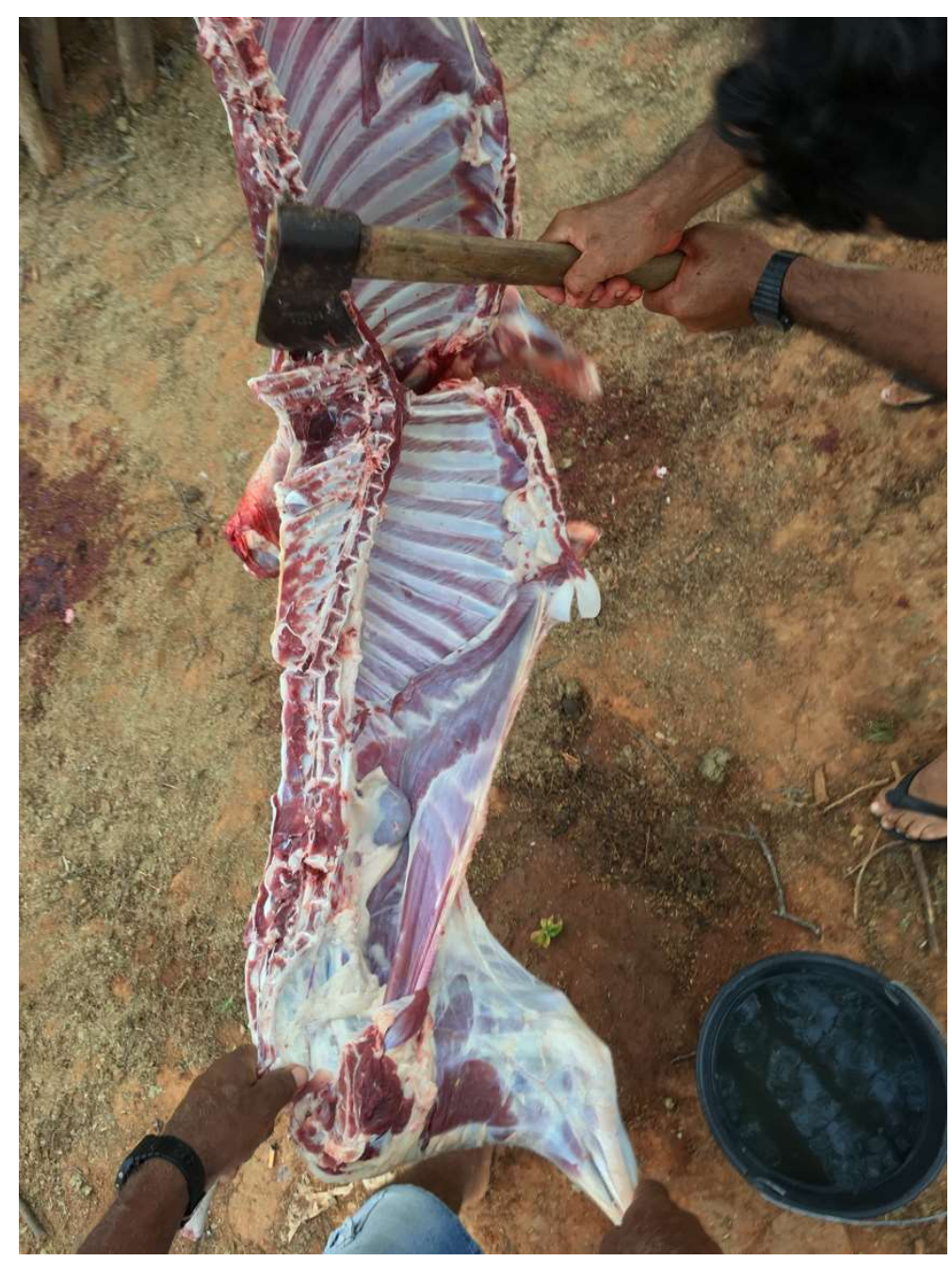




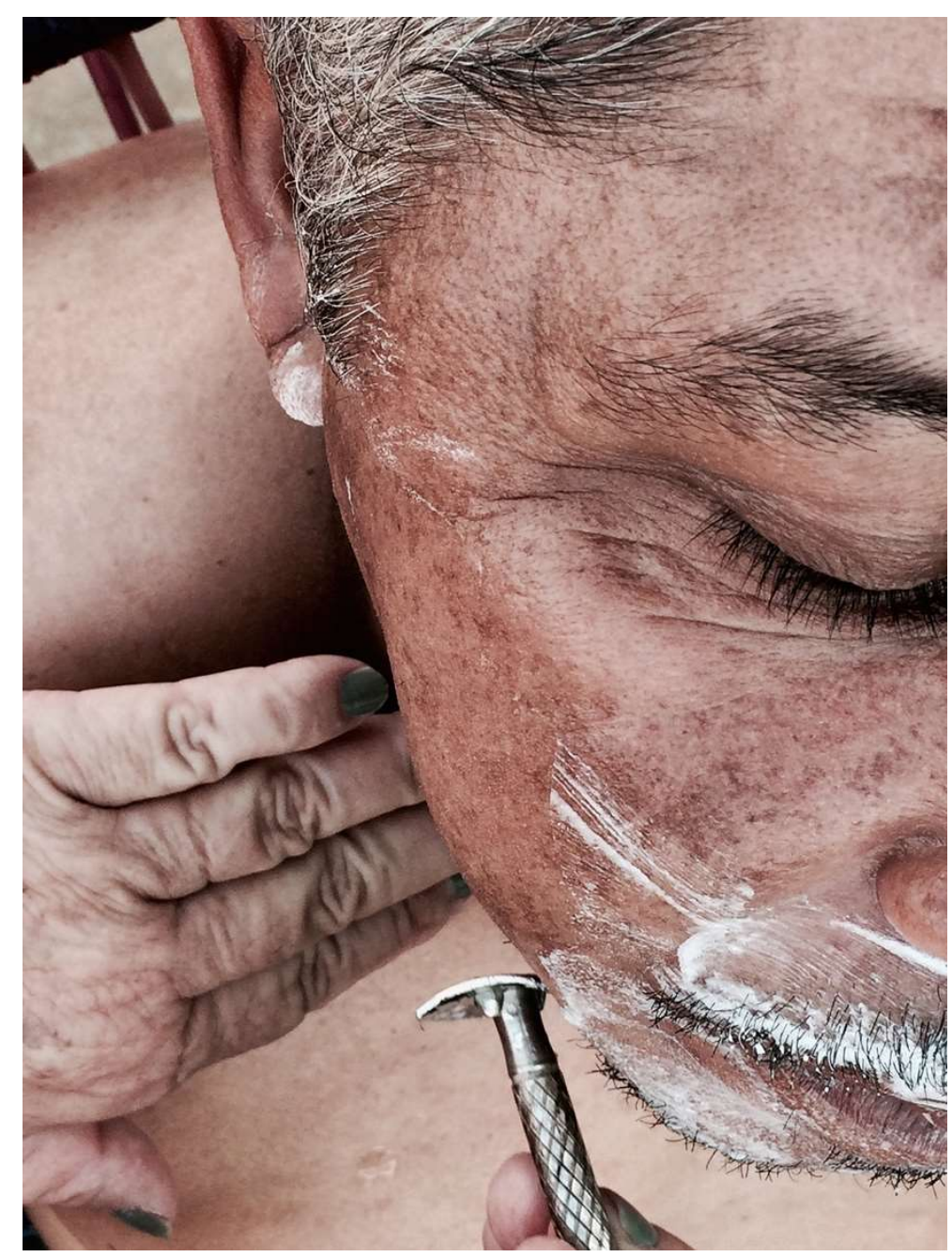



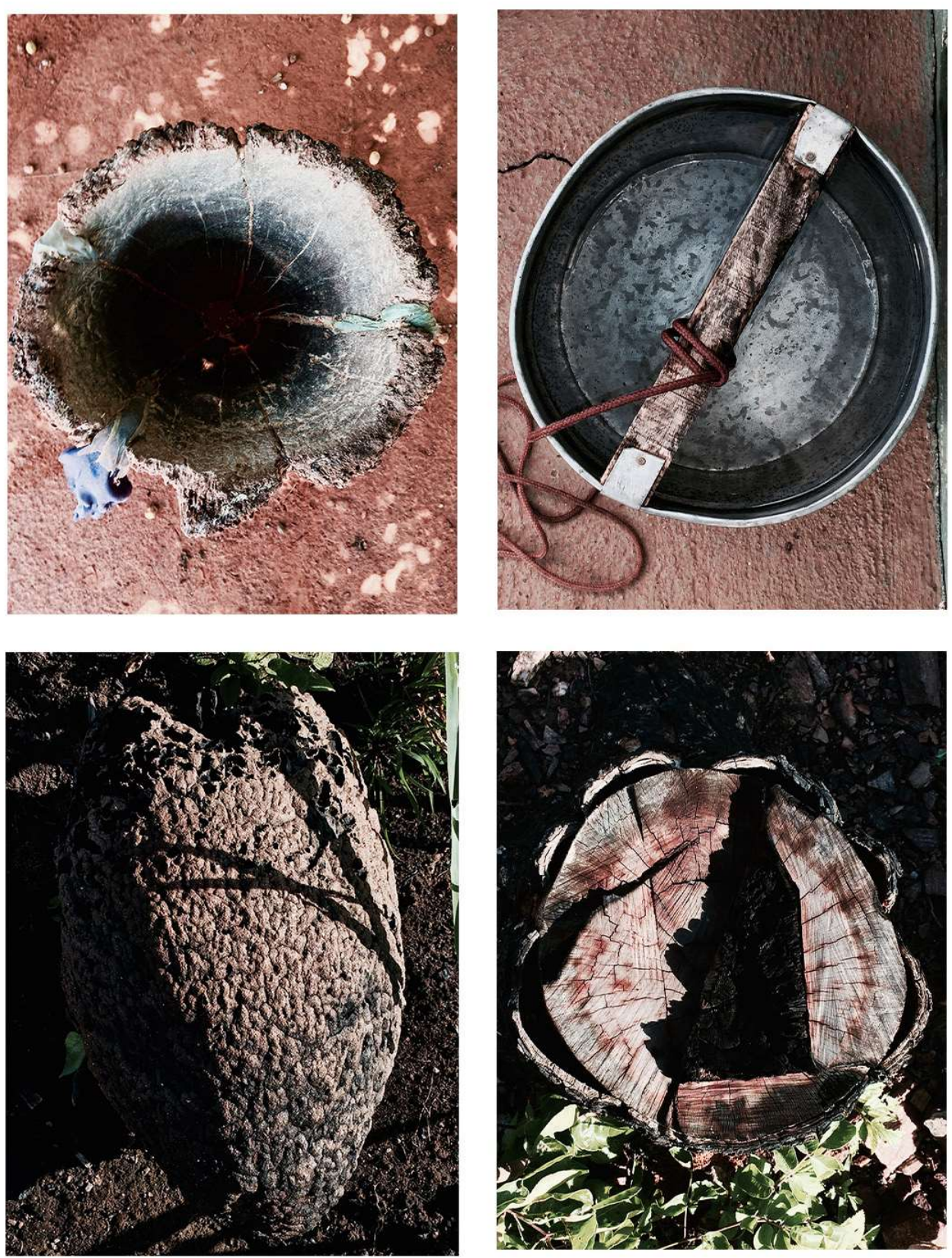


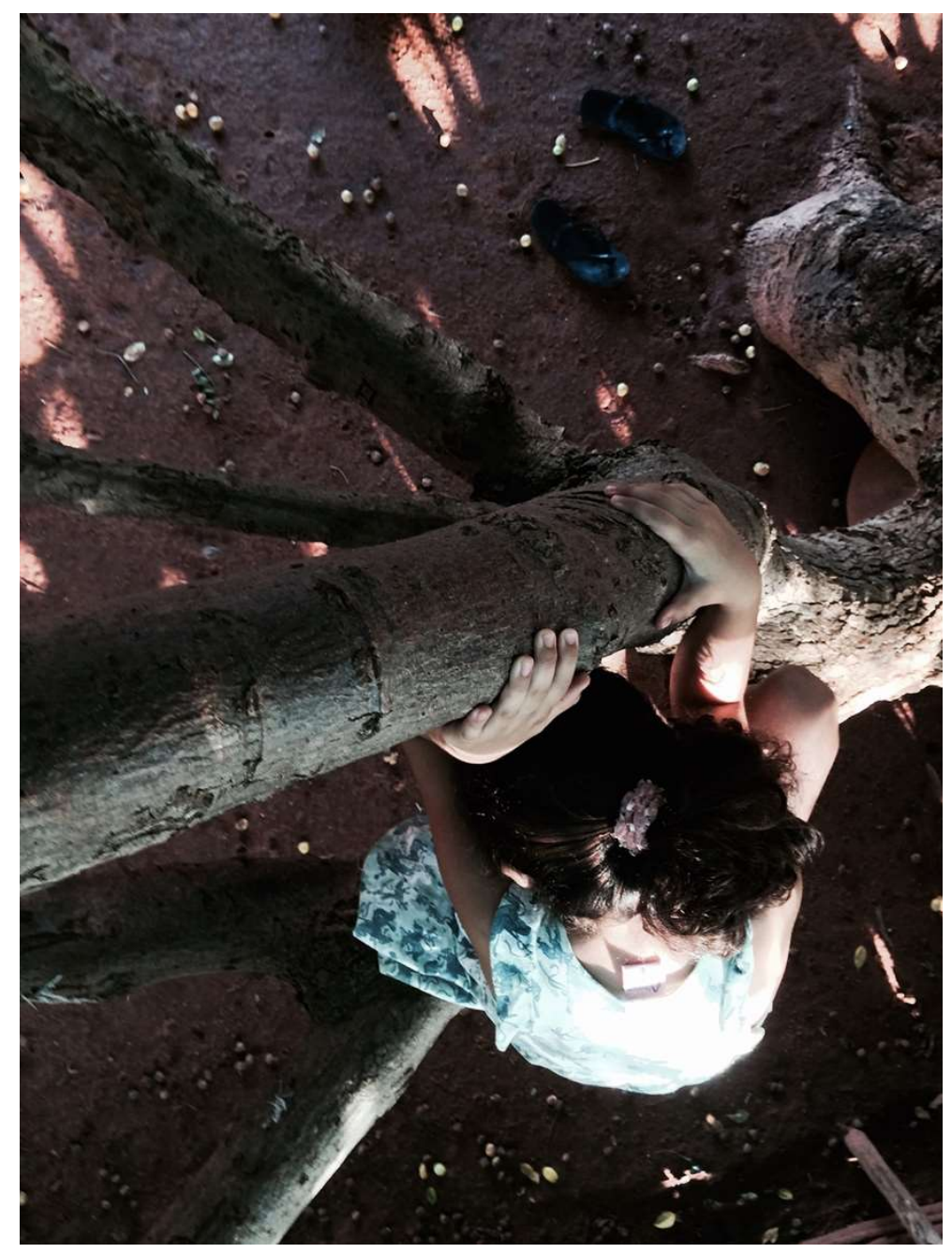



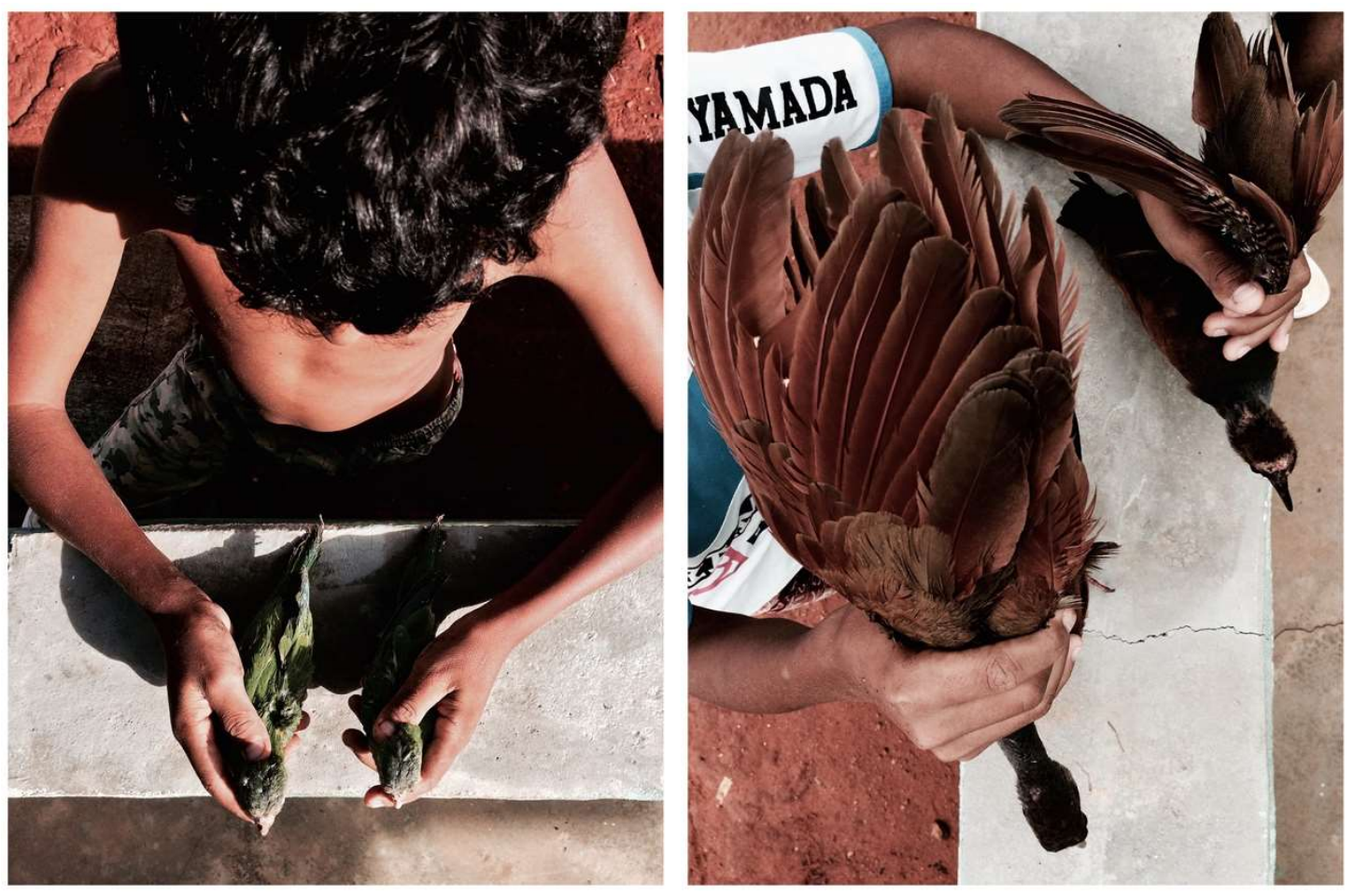


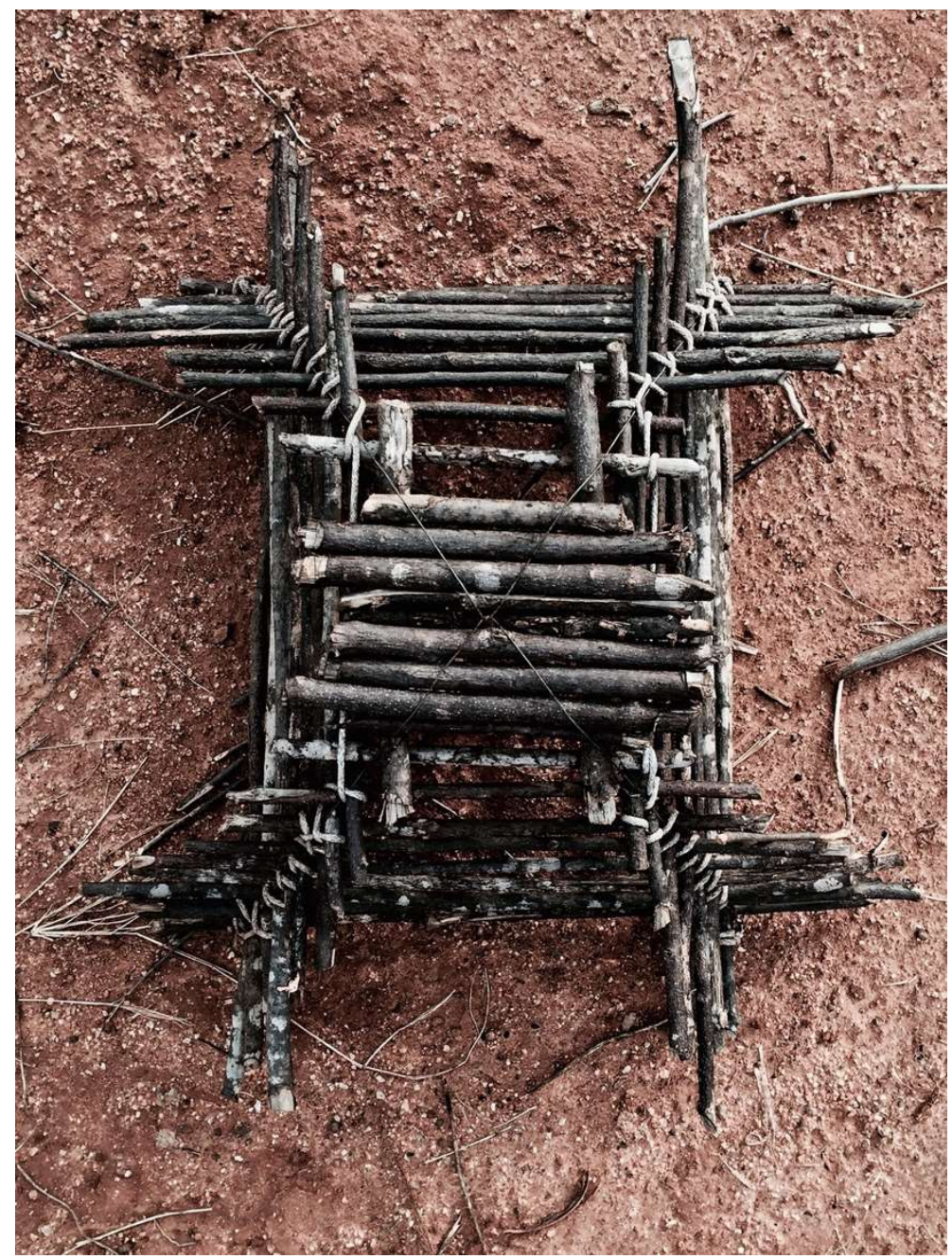



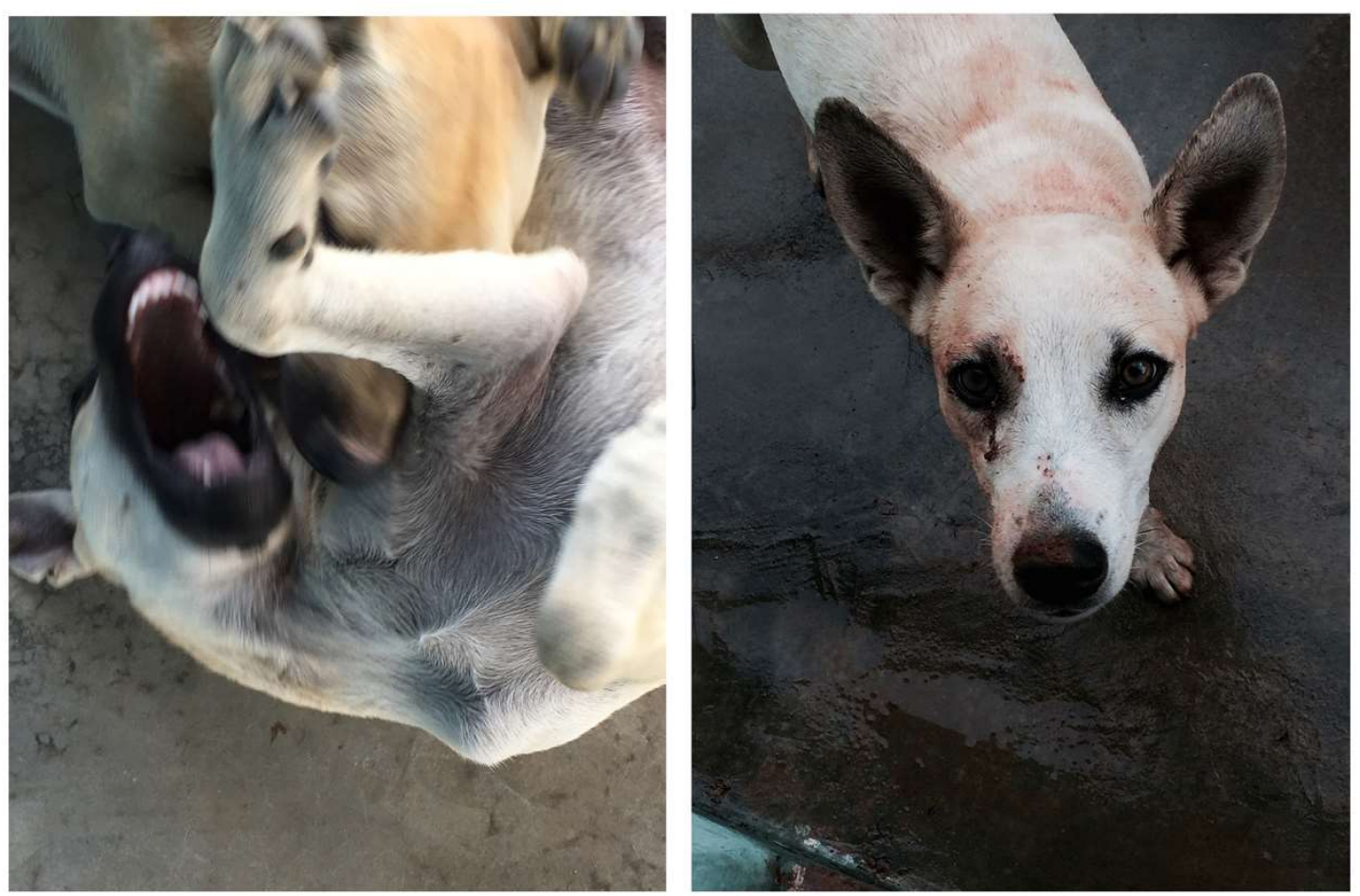


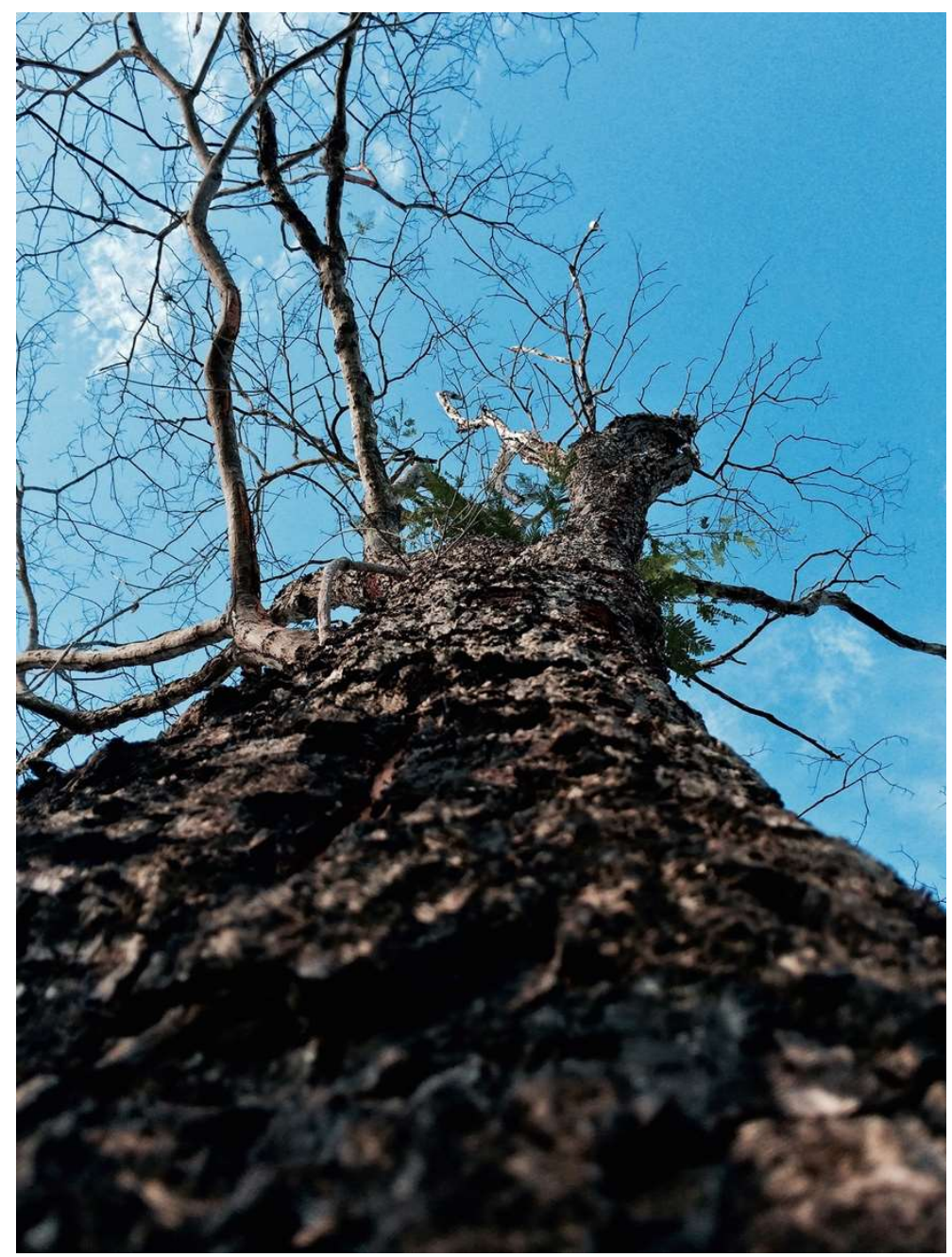




\section{REFERÊNCIAS}

ACHUTTI, Luiz Eduardo Robinson. Fotoetnografia: um estudo de Antropologia Visual sobre cotidiano, lixo e trabalho. Porto Alegre: Tomo Editorial, Palmarinca, 1997.

ANDUJAR, Claudia. A vulnerabilidade do ser. São Paulo: Cosac Naify, Pinacoteca do Estado, 2005.

BARTHES, Roland. A câmara clara: nota sobre a fotografia. Rio de Janeiro: Nova Fronteira, 1984.

BENJAMIN, Walter. Obras escolhidas: magia e técnica, arte e política. 3.ed. São Paulo: Brasiliense, 1987.

CASTILHO, João; DAVID, Pedro \& MOTTA, Pedro. Paisagem submersa. São Paulo: Cosac Naify, 2008.

CLIFFORD, James. Sobre a autoridade etnográfica. In: - A experiência etnográfica: antropologia e literatura no século XX. 3.ed. Rio de Janeiro: Editora UFRJ, 2008. p.17-59.

COMERFORD, John Cunha. Fazendo a luta: sociabilidade, falas e rituais na construção de organizações camponesas. Rio de Janeiro: Relume Dumará, 1999.

FONTCUBERTA, Joan. O beijo de Judas: fotografia e verdade. Barcelona: Editorial Gustavo Gili, 2010.

MARRAS, Stelio. Virada animal, virada humana: outro pacto. Scientiae studia, v.12, n.2, p.215-60, 2014.

MEYER, Doris Rinaldi. A terra de santo e o mundo dos engenhos: estudo de uma comunidade rural nordestina. Rio de Janeiro: Paz \& Terra, 1979. 
PALMEIRA, Moacir. Casa e trabalho: notas sobre as relações sociais na plantation tradicional, Revista de Ciências Sociais do Centro de Estudos Noel Nutels, n.2, 1977, p.103-114.

Feira e mudança econômica, Vibrant, v.11, n.1, p.324-360, 2014 [1971].

PINHEIRO, Sophia Ferreira. Jaexá va'e Jo hetere re: “o corpo que enxergamos". Iluminuras, v.18, n.43, p.361-367, 2017.

SAER, Juan José. O conceito de ficção. Sopro: panfleto político-cultural, n.15, p.1-4, 2009.

SAMAIN, Etienne. "Ver" e "Dizer" na tradição etnográfica: Bronislaw Malinoski e a fotografia. Horizontes Antropológicos, v.1, n.2, p.23-60, 1995.

SANTANA, Tiago. Benditos. Fortaleza: Tempo d'Imagem, 2000.

SANTANA, Tiago \& DANTAS, Audálio. O chão de Graciliano. Fortaleza: Tempo d'Imagem, 2006.

SIGAUD, Lygia. A nação dos homens: uma análise regional de ideologia. Anuário Antropológico/78, Rio de Janeiro: Tempo Brasileiro, 1978, p.13-114

Os clandestinos e os direitos: estudo sobre trabalhadores da cana-de-açúcar de Pernambuco. São Paulo: Duas Cidades, 1979.

SORDI, Caetano. A pelo y pluma: episódios de caza menor na província de Sevilha, Andaluzia, Espanha. Iluminuras, v.17, n.42, p.543-554, 2016.

SÜSSEKIND, Felipe. Sobre a vida multiespécie. Revista do Instituto de Estudos Brasileiros, n.69, p.159-178, 2018.

TEIXEIRA, Jorge Luan. Dissertação de mestrado. 2014a. 
Ensaio fotográfico. 2014b.

. Tese de doutorado. 2019.

TEIXEIRA, Jorge Luan Rodrigues; AYOUB, Dibe Salua. Cachorros que atacam criação: reflexões éticas sobre a mobilidade e a vida social dos animais em ambientes rurais. Revista Iluminuras, v. 17, p. 136-165, 2016.

TSING, Anna. Margens indomáveis: cogumelos como espécies companheiras. Ilha, v.17, n.1, p.177-201, 2015.

Recebido: 03/12/2021

Aprovado: 09/03/2021 